\title{
Changes in Morphology and Activity of Transglutaminase Following Cross-Linking and Immobilization on a Polypropylene Microporous Membrane
}

\author{
Yan-Guo Shi ${ }^{1}$, Lei Qian ${ }^{1}$, Na Zhang ${ }^{1}$, Chun-Ran Han ${ }^{1}$, Ying Liu ${ }^{1}$, Yi-Fang Zhang ${ }^{2}$ and \\ Yong-Qiang Ma ${ }^{1, *}$
}

1 Key Laboratory of Food Science and Engineering of Heilongjiang Province, Harbin University of Commerce, Harbin 150076, China

2 Harbin Hi-tech Soybean Food Co. Ltd., Harbin 150078, China

* Author to whom correspondence should be addressed; E-Mail: mayq@hrbcu.edu.cn, Tel.: +86-451-8753-7112, Fax: +86-451-8484-4281.

Received: 4 November 2011; in revised form: 28 November 2011 / Accepted: 30 November 2011 / Published: 5 December 2011

\begin{abstract}
Transglutaminase (TGase) was cross-linked with glutaraldehyde, and crosslinked crystalline transglutaminase was immobilized on a polypropylene microporous membrane by UV-induced grafting. Immobilized enzyme activity were calculated to be $0.128 \mathrm{U} / \mathrm{cm}^{2}$ polypropylene microporous membrane. The microstructure and enzyme characteristics of free, cross-linked and immobilized transglutaminase were compared. The optimum temperature of free transglutaminase was determined to be approximately $40{ }^{\circ} \mathrm{C}$, while cross-linking and immobilization resulted in an increase to approximately $45{ }^{\circ} \mathrm{C}$ and $50{ }^{\circ} \mathrm{C}$. At $60{ }^{\circ} \mathrm{C}$, immobilized, cross-linked and free transglutaminase retained $91.7 \pm 1.20 \%$, $63.2 \pm 1.05 \%$ and $37.9 \pm 0.98 \%$ maximum activity, respectively. The optimum $\mathrm{pH}$ was unaffected by the state of transglutaminase. However, the thermal and $\mathrm{pH}$ stabilities of cross-linked and immobilized transglutaminase were shown to increase.
\end{abstract}

Keywords: transglutaminase; cross-linking; immobilization; enzyme activity; microstructure

Abbreviations: grafting degree (GD); scanning electron microscopy (SEM); standard deviation (SD); trichloracetic acid (TCA); transglutaminase (TGase) 


\section{Introduction}

Transglutaminase (TGase; protein-glutamine-glutamyltransferase, EC 2.3.2.13). catalyzes the acyl-transfer reaction in which the $\gamma$-carboxyamide groups of glutamine residues in proteins, peptides and various primary amines, act as acyl donors and primary amino groups including $\varepsilon$-amino groups of lysine residues, either as peptide-proteins bound or free lysine, act as the acyl acceptors [1-5]. These reactions are dependent on a number of factors, including $\mathrm{pH}$ and temperature. Transglutaminases present in most animal tissues and body fluids are involved in several biological processes, including blood clotting, wound healing, epidermal keratinization, and stiffening of the erythrocyte membrane [6].

Intra- and intermolecular cross-linking as well as the addition of peptide or other moieties to proteins has the potential for causing desirable changes in functionality [7]. For example, transglutaminase has been used to form gels [8-12], to form cross-linked hompolymers or heteropolymera of proteins [13-18], and to introduce other moieties into the protein structure [19,20]. Industrially, TGase is mainly used to improve the texture, stability, and other functional properties of food products. In the meat industry, using transglutaminase to cross-link proteins has been found feasible. The TGase enzyme catalyzes cross-linking between protein molecules [21]. The TGase currently utilized has a microbiological origin, which has been tested in the manufacture of several meat and fish products [22]. Kuraishi et al. [23] have developed the new meat-binding system using TGase and caseinate simultaneously. Seki et al. [24] found that endogenous fish TGase caused 'suwari' setting, hardening fish protein paste at low temperature through crosslinking. In another study, Moore et al. [25] reported that gluten-free batter (prepared from rice flour, potato starch, corn flour and xanthan gum) enriched with skim milk powder or egg white and treated with TGase promoted covalent bond formation between lysine and glutamine residues in the proteins and improved the protein network of the batter. TGase from walleye pollack, fish for surimi, has been purified and characterized by Kumazawa et al. [26]. Otherwise, many researchers have shown that TGase can be used in the processing of dairy, wheat and soybean products in order to improve texture, water-holding capacity, elasticity, nutritional value and appearance [27-34].

Enzyme stabilization [35] is one of the major challenges in the biocatalytic process optimization. Enzymes have to be used at higher temperatures, shear rate and organic solvent environments for the production [36] of pharmaceuticals, agrochemicals, consumer care products, etc. Cross-linked enzyme crystals technology [37] is one of the most exciting developments in the area of biocatalysis. Cross-linked enzyme crystals are prepared by controlled precipitation of enzymes into microcrystals followed by cross-linking using bifunctional reagents to form strong covalent bond between free amino acid groups in the enzyme molecules [38]. In a cross-linked enzyme crystal, the lattice interactions in the enzyme crystal when fixed by inter- and intramolecular chemical cross-links provide additional physical and thermal stability. A protein in cross-linked crystal is stabilized by links in all three-dimensional structure. Hence, cross-linked enzyme crystals are highly active, recyclable and having good mechanical stability.

Immobilization of enzymes is one of the techniques used by the industries to bring down the cost of the process by reusing the enzymes. Sangha [39] examine the possibility of using an immobilized form of transglutaminase for cross-linking of proteins. Transglutaminase was covalently immobilized on poly(lysy1)- $\alpha$-casein which was covalently attached to 3 -aminopropyl porous glass. This represents the 
first study of a covalently immobilized form of this enzyme. However, information regarding the microstructure and enzyme characteristics of immobilized transglutaminase is limited.

In this study, transglutaminase was cross-linked and immobilized on a polypropylene microporous membrane to improve the enzyme characteristics. The surface of polypropylene microporous membranes was activated by UV-induced graft polymerization of methyl methacrylate to improve the poor biocompatibility of this membrane and activity of the enzyme. Scanning electron microscopy (SEM) was used to study the microstructure of the free, cross-linked and immobilized crystalline transglutaminase. The optimal temperature and $\mathrm{pH}$ conditions for transglutaminase activity were determined in addition to analysis of thermal and $\mathrm{pH}$ stabilities.

\section{Results and Discussion}

Units of enzyme activity immobilized on spacers were calculated to be $0.128 \mathrm{U} / \mathrm{cm}^{2}$ polypropylene microporous membrane. The activity of immobilized enzyme was measured using the hydroxamate method relative to the total amount of protein estimated by the Bradford assay and was calculated to be $31.2 \mathrm{U} / \mathrm{mg}$, which was lower than that of free enzyme $(102.8 \mathrm{U} / \mathrm{mg})$. It can be speculated that the loading capacity and activity of the immobilized enzyme is attributed to the surface properties of the polypropylene microporous membrane of polymeric spacers such as coarseness and hydrophilicity.

\subsection{SEM Investigations}

Surface characteristics and cross-sectional morphology of free, cross-linked and immobilized transglutaminase and polypropylene microporous membranes were analyzed by SEM (Figure 1).

Figure 1. SEM photomicrographs of free transglutaminase (a) cross-linked transglutaminase (b), polypropylene microporous membrane in the absence of (c) and with (d) the cross-linked transglutaminase (magnification $\times 5,000$ ).

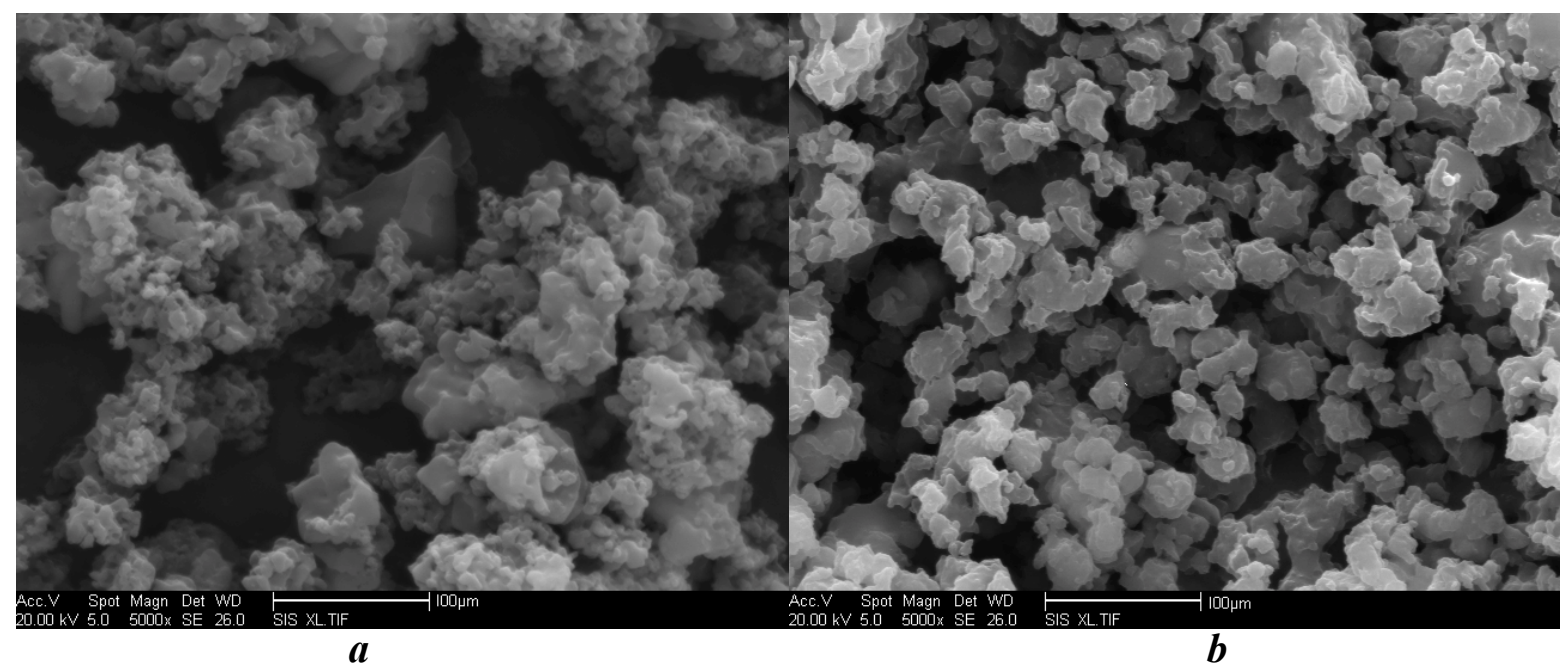


Figure 1. Cont.

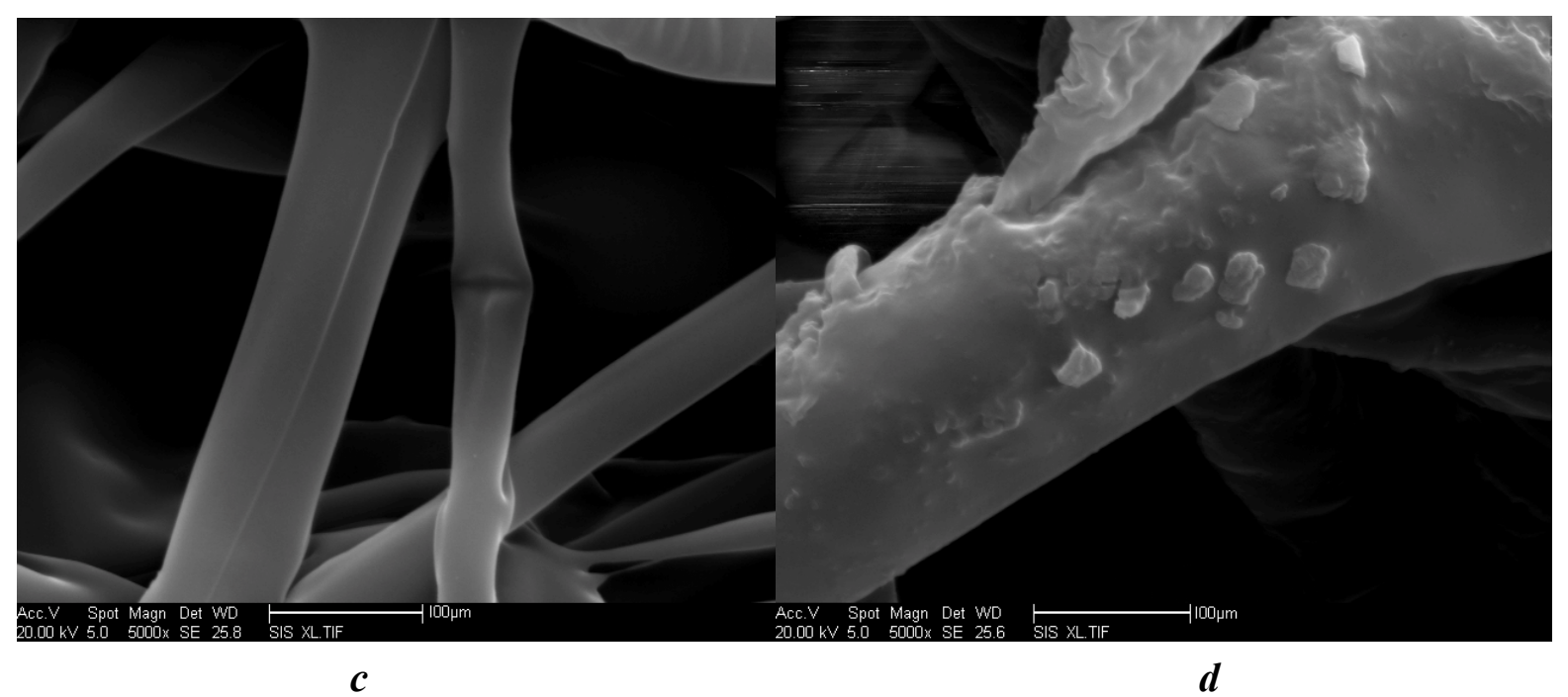

The size of free transglutaminase was not uniform, and the shape was irregular (Figure 1a). However, the particle size of cross-linked transglutaminase was greater and the boundaries more distinct. Particle shape was that of an irregular polyhedron (Figure 1b). Furthermore, the spatial molecular configuration of cross-linked transglutaminase was altered from that of the free enzyme. The surface fibers of the native polypropylene microporous membrane were relatively smooth with an irregular, crossed arrangement (Figure 1c). However, after immobilization, the surface of fibers of the polypropylene microporous membrane were more coarse, with particles of uniform size adhered to the surface (Figure 1d). The density of these particles on the fiber surface was high and furthermore, the form of the particles was similar to that of cross-linked transglutaminase (Figure 1b). These observations confirmed immobilization of cross-linked transglutaminase onto the surface of the polypropylene microporous membrane.

\subsection{Optimal Temperature and $\mathrm{pH}$}

The influence of temperature and $\mathrm{pH}$ on enyme activity of cross-linked and immobilized transglutaminase was investigated relative to that of the free enzyme. The temperature profiles of free, cross-linked and immobilized transglutaminase were measured by incubating the enzyme at 30, 35, 37, $40,45,50,55$ and $60^{\circ} \mathrm{C}$ for $10 \mathrm{~min}$, respectively.

The optimum temperature of free transglutaminase was determined to be approximately $40{ }^{\circ} \mathrm{C}$. However, cross-linking and immobilization resulted in an increase to approximately $45{ }^{\circ} \mathrm{C}$ and $50{ }^{\circ} \mathrm{C}$, respectively, thus indicating a significant alteration of enzyme microenvironment on the polypropylene microporous membrane surface. This suggests that crosslinking and immobilization results in strengthening of the enzyme structure and provides a protective effect against heat denaturation.

The activities of the enzymes at different temperatures were expressed relative to the maximum activity of free, cross-linked and immobilized crystalline transglutaminase at the optimum temperatures of 40,45 and $50{ }^{\circ} \mathrm{C}$ respectively (Figure 2). At $60{ }^{\circ} \mathrm{C}$, immobilized, cross-linked and free transglutaminase retained $91.7 \pm 1.20 \%, 63.2 \pm 1.05 \%$ and $37.9 \pm 0.98 \%$ maximum activity respectively. 
Figure 2. Temperature profile of free, cross-linked and immobilized transglutaminase.

Data are expressed relative to the maximal enzyme activity.

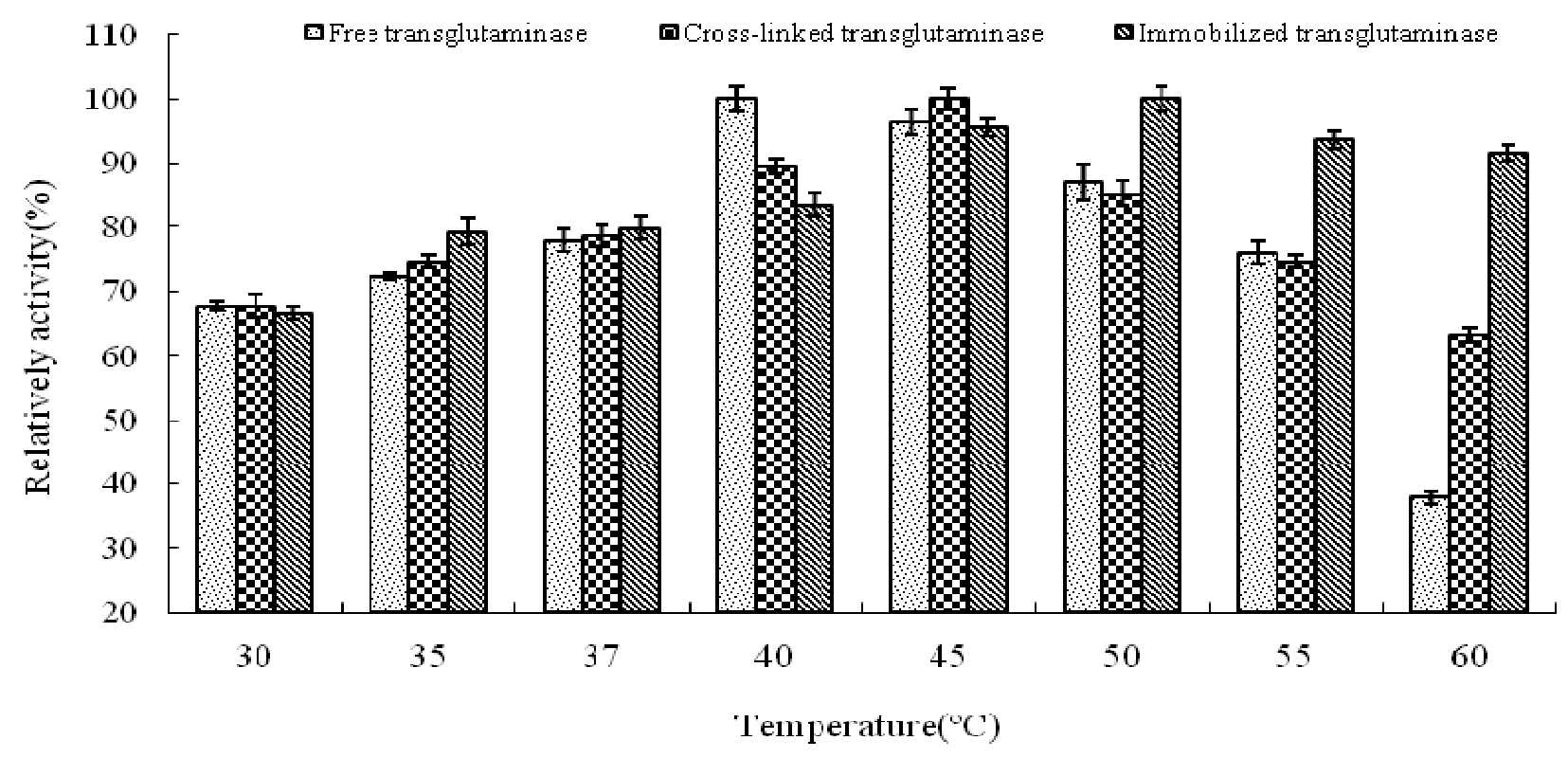

These results indicate that the optimal temperature of transglutaminase activity was altered by the state of the enzyme and was attributed to the cross-linking treatment and immobilization. The immobilization procedure seems to protect the enzymatic configuration from distortion or damage by heat exchange and as a result; immobilized enzyme could work in tougher environment with minimal activity loss.

$\mathrm{pH}$ is known to be a significant parameter responsible for alteration in enzymatic activity in aqueous solution. In this study, the effect of $\mathrm{pH}$ on the activity of free, cross-linked and immobilized transglutaminase was studied at a range of $\mathrm{pH}$ values at $37{ }^{\circ} \mathrm{C}$ (Figure 3). The optimum $\mathrm{pH}$ of free transglutaminase was determined to be 6.0 and was not altered by cross-linking or immobilization.

Figure 3. $\mathrm{pH}$ profile of free, cross-linked and immobilized transglutaminase. Data are expressed relative to the maximal enzyme activity.

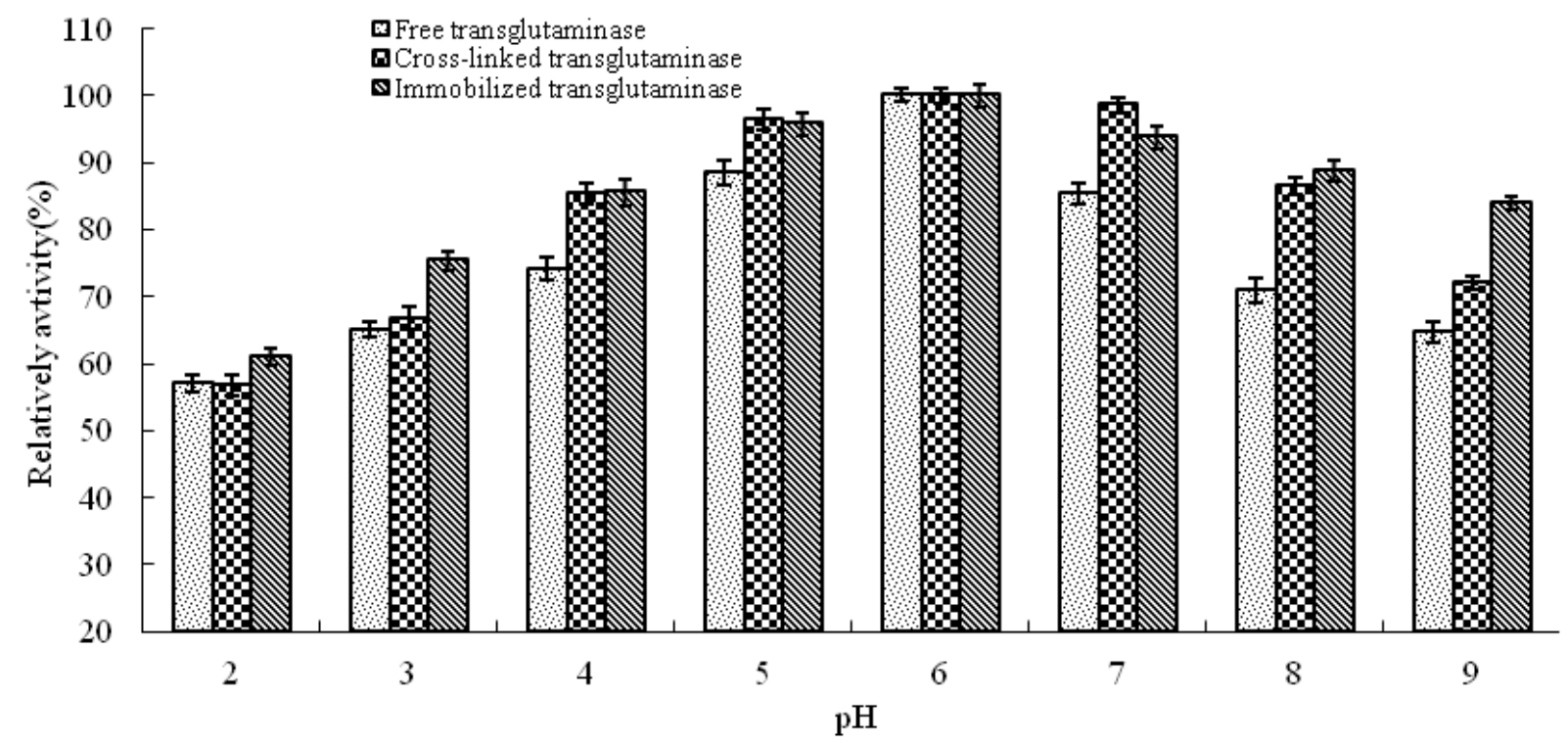




\subsection{Thermal and $p H$ Stabilities}

The thermal stabilities of free, cross-linked and immobilized transglutaminase were determined in terms of the residual activities compared with the control (Figure 4). The activity of cross-linked and immobilized transglutaminase increased significantly in comparison to that of the free trans-glutaminase at all temperatures investigated. After $120 \mathrm{~min}$ incubation at $80{ }^{\circ} \mathrm{C}$, the residual activities of free, cross-linked and immobilized transglutaminase were $23.2 \pm 1.05 \%, 72.6 \pm 1.86 \%$ and $74.8 \pm 2.06 \%$, respectively. These data demonstrate that crosslinking treatment or immobilization of transglutaminase on polypropylene microporous membrane led to a significant stabilizing effect with regard to heat inactivation.

The cross-linked and immobilized transglutaminase maintains its native conformation at elevated temperature and having lower tendency to aggregate. This is because in cross-linked enzyme crystals, the enzyme molecules are symmetrically arranged and hence their native conformation is stabilized. When an enzyme forms a crystal, a very large number of stabilizing contacts are formed between individual enzyme molecules [40]. Energy must be put into the system in order to disrupt these new contacts, so that additional energy is required to break the covalent cross-links before the cross-linked enzyme begins to dissolve and then denature. The increased thermal stability is also due to the pre-ordered arrangement of the molecules by inter- and intramolecular cross-links between the crystals, and hence the rigidity of the three-dimensional arrangement of molecules in the cross-linked enzyme crystals [41].

Figure 4. Thermal stabilities of the free, cross-linked and immobilized transglutaminase at different temperatures. Data are expressed as the \% residual enzyme activity compared with the control.

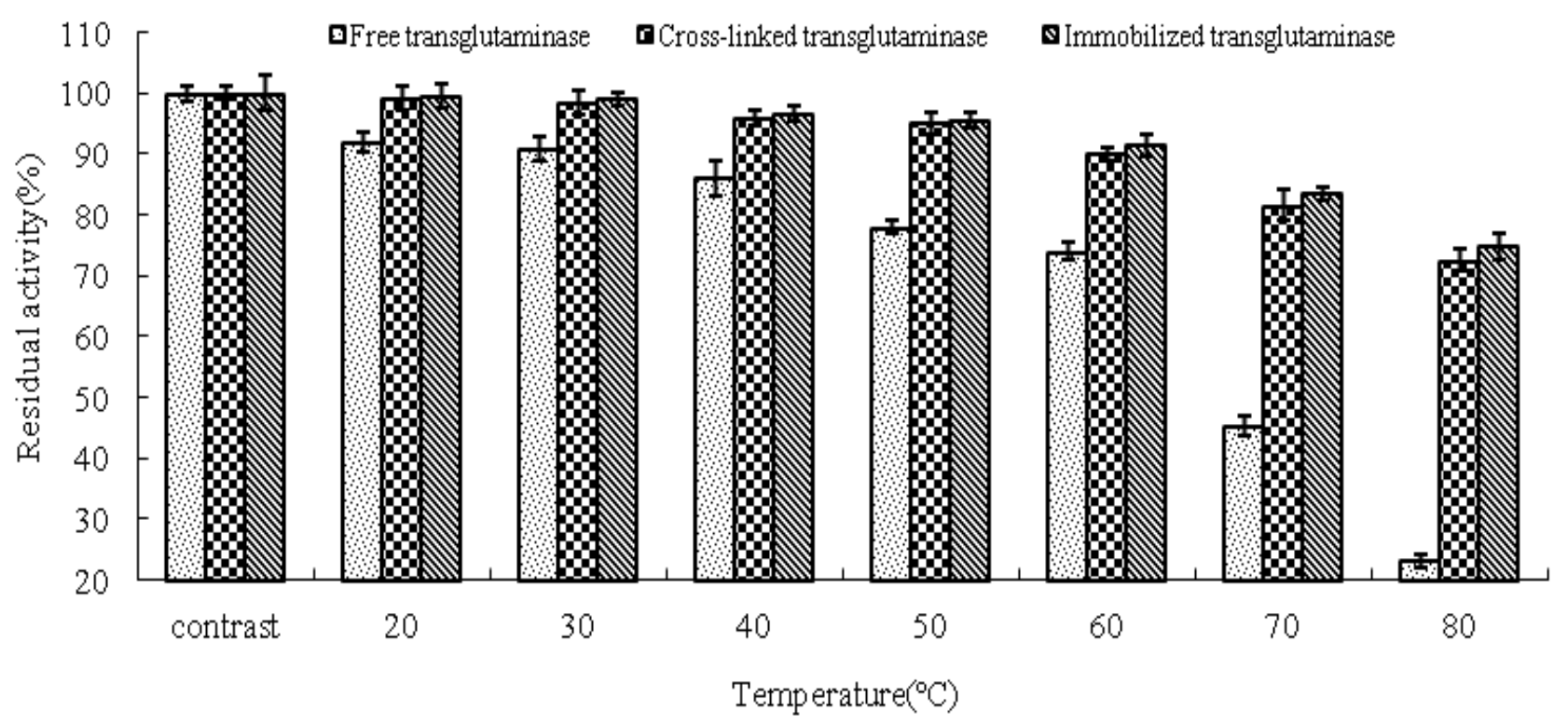

The effect of $\mathrm{pH}$ on the residual activity of free, cross-linked and immobilized transglutaminase was studied by varying the $\mathrm{pH}$ of the reaction medium from $\mathrm{pH} 2.0$ to $\mathrm{pH} 9.0$ (Figure 5). Immobilization has been shown to result in stabilization of enzyme activity over a broad range of $\mathrm{pH}$ values. Under alkaline $\mathrm{pH}$ values $(\mathrm{pH} 8-9)$, free transglutaminase retained $24 \pm 1.88 \%$ residual activity whereas, 
cross-linked and immobilized transglutaminase retained $60.1 \pm 1.05 \%$ and $62.5 \pm 1.62 \%$ activity, respectively. These data indicate that cross-linking treatment and immobilization provide a protective effect on enzyme activity at high $\mathrm{pH}$ compared with free transglutaminase.

Figure 5. $\mathrm{pH}$ stabilities of free, cross-linked and immobilized transglutaminase at different $\mathrm{pH}$ values. Data are expressed as the \% residual enzyme activity compared with the control.

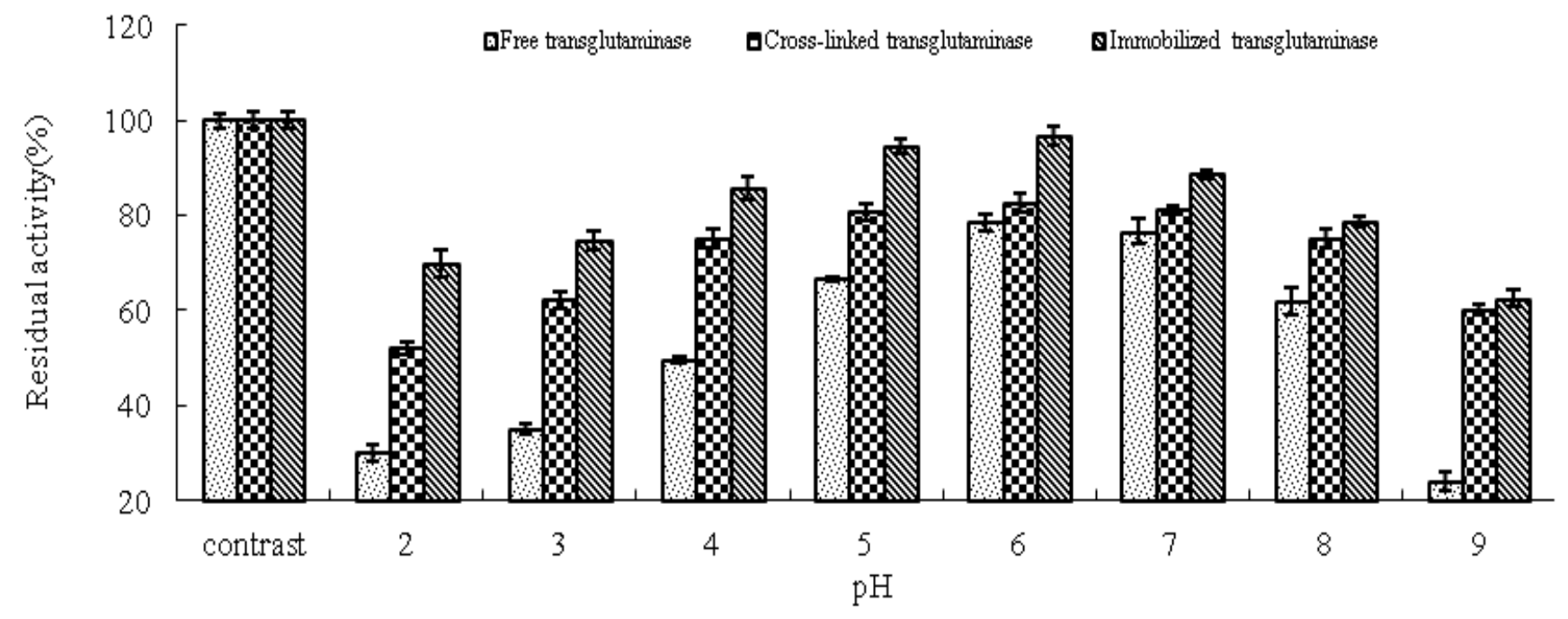

This $\mathrm{pH}$ shift towards the alkaline side is due to the secondary interactions between the coupling agent and the enzyme. The change in pH stabilities depends on the charge of the enzyme and/or the matrix. The glutaraldehyde coupling of the matrix with the enzyme would have linked all the available amino groups on the surface of the enzyme, and hence the acidic groups on the enzyme surface gives a negative charge to the enzyme protein, ultimately increasing $\mathrm{pH}$ stabilities. The cross-linking procedure could significantly improve the enzymatic resistance against $\mathrm{pH}$ shift. Immobilization brought about enhanced $\mathrm{pH}$ stability. This may be due to the changes inflicted on the enzyme on account of the strong covalent bond formed between the support and the enzyme. Strong interactions between enzyme and support will affect the intra-molecular forces responsible for maintaining the conformation of the enzyme that would lead to a change in activity [42].

The thermal and $\mathrm{pH}$ stability of enzymes are very important parameters in enzyme reactor designs, as they determine the limits for use and reuse of the enzyme, and therefore process costs [43]. Crosslinked and immobilized transglutaminase have the additional advantage of good stability, and can be used in immobilized enzyme reactor to work on the polymerization and entrapment function of soybean protein. The enzyme reactor can retrieve the soy whey protein and minimize the pollution of soybean whey wastewater.

\section{Experimental}

\subsection{Materials}

Unless otherwise stated, all chemicals, reagents and solvents were of analytical grade. reduced glutathione hormone, N- $\alpha$-CBZ-Gln-Gly, L-Glutamic acid $\gamma$-monohydroxamic acid were purchased from Sigma Chemical Company Ltd. Methyl methacrylate, diaminohexane and glutaraldehyde were 
purchased from the Tianjin Kermel Chemical Reagent Company Ltd. (Tianjin, China). Polypropylene microporous membrane (average pore diameter, $10 \mu \mathrm{m}$ ) was purchased from ZhongXin Company Ltd. (Beijing, China).

\subsection{Enzyme Preparation}

Transglutaminase derived from Streptoverticillium was obtained from Yiming Biological Products Company Ltd. (Jiangsu, China). As determined by a colorimetric hydroxamate method [44], the enzyme activity of MTGase was $9.86 \mathrm{U} / \mathrm{mg}$ of powder. The transglutaminase was purified through alcohol precipitation, ammonium sulphate precipitation, ultrafiltration and gel layer chromatography. The activity of purified enzyme was $102.8 \mathrm{U} / \mathrm{mg}$.

\subsection{Preparation of Transglutaminase Minicrystals}

Sitting-drop vapor diffusion crystallization experiments were performed at $4{ }^{\circ} \mathrm{C}$ in 24 -well Chryschem plates (type HR3-158, Hampton Research Corp., Aliso Viejo, CA, USA) sealed with Crystal Clear sealing tape (Manco Inc., Avon, OH, USA). $10 \mathrm{~mL}$ rarefied transglutaminase solution $(15 \mathrm{mg} / \mathrm{mL}$ ) was added to $10 \mathrm{~mL} \mathrm{50 \%} \mathrm{2-methyl-2.4-amyldiethanol} \mathrm{in} \mathrm{sitting-drop} \mathrm{trays} \mathrm{(diameter,}$ approx. $6 \mathrm{~mm}$; maximum filling volume, approx. $40 \mathrm{~mL}$ ). The reservoir solution contained $30 \mathrm{mM}$ phosphate buffer (137 mM NaCl, $2.7 \mathrm{mM} \mathrm{KCl}, 4.3 \mathrm{mM} \mathrm{Na}_{2} \mathrm{HPO}_{4}, 1.4 \mathrm{mM} \mathrm{KH}_{2} \mathrm{PO}_{4}, \mathrm{pH} 8.0$ ) as the crystallization agent. After crystallization for 5 days, the crystalloid solution of transglutaminase was centrifuged at $1,000 \mathrm{rpm} / \mathrm{min}$ for $5 \mathrm{~min}$. The total transglutaminase and protein content of the original solution and resulting supernatant respectively, were determined by lowry method. The transglutaminase crystal content was calculated by the following equation:

Transglutaminase crystal content $(\mathrm{mg} / \mathrm{mL})=$ total protein content of $10 \mathrm{~mL}$ transglutaminase solution $(\mathrm{mg} / \mathrm{mL})$ - protein content of supernatant solution $(\mathrm{mg} / \mathrm{mL})$.

\subsection{Transglutaminase Minicrystal Cross-Linking}

Transglutaminase minicrystals $(50 \mathrm{mg})$ were cross-linked with $1 \%$ glutaraldehyde (pentanedial, $125 \mathrm{~mL}$ ) at $4{ }^{\circ} \mathrm{C}$ in sodium acetate buffer (sodium acetate $54.6 \mathrm{~g}, 20 \mathrm{~mL}$ of $1 \mathrm{M}$ acetic acid solution, diluted with deionized water to $500 \mathrm{~mL}, \mathrm{pH} \mathrm{6.0)}$. The solution was stirred for $40 \mathrm{~min}$ and then filtered. The precipitate was collected and washed with deionized water several times before being washed with sodium acetate buffer ( $\mathrm{pH}$ 6.0), until the UV value of effluent at $280 \mathrm{~nm}$ was below 0.5 . The precipitate was lyophilized to produce the cross-linked transglutaminase crystalline powder.

\subsection{Immobilization of Poly(methyl methacrylate)-Grafted Polypropylene Microporous Membrane}

\subsubsection{Pretreatment of Polypropylene Microporous Membrane}

Prior to grafting, polypropylene microporous membranes were pre-treated with acetone for $24 \mathrm{~h}$ to remove any impurities adsorbed onto the surface, dried in a vacuum oven at $30^{\circ} \mathrm{C}$ to constant weight (W0) and stored in a desiccator. 


\subsubsection{Preparation of Poly(methyl methacrylate)-Grafted Polypropylene Microporous Membranes}

Poly(methyl methacrylate)-grafted polypropylene microporous membrane was prepared by UV-induced graft polymerization. Pre-treated membrane (W0) was immersed in benzophenone dissolved in acetone ( $0.2 \mathrm{mM}$ final concentration) and simultaneously exposed to UV at a distance of $10 \mathrm{~cm}$ for $12 \mathrm{~min}$. The membrane was dried in air, immersed in ethanol containing 20\% methyl methacrylate and exposed to UV for $20 \mathrm{~min}$. These reactions were performed under nitrogen gas.

Finally, the modified membrane was washed with acetone for $24 \mathrm{~h}$ at $30{ }^{\circ} \mathrm{C}$ with agitation to remove adsorbed monomer and homopolymer. After being dried to constant weight in a vacuum oven at $30{ }^{\circ} \mathrm{C}$, the membrane was weighed (W) with an analytical balance to a precision of $0.1 \mathrm{mg}$. The grafting degree (GD) of poly(methyl methacrylate) was calculated by the following equation:

$$
\mathrm{GD}=\left(\frac{W-W o}{W o}\right) \times 100 \%
$$

where $\mathrm{W}_{0}$ is the mass of the native polypropylene microporous membrane. Each result was the average of three parallel experiments.

\subsubsection{Introduction of the Diaminohexane Spacer Arm}

Poly(methyl methacrylate)-grafted polypropylene microporous membranes were transferred to $20 \%$ diaminohexane solution. The reaction was carried out at $50{ }^{\circ} \mathrm{C}$ for $90 \mathrm{~min}$. Membranes were washed under running deionized water to eliminate adsorbed diaminohexane.

\subsubsection{Activation of Amino Groups}

The activation of the polypropylene microporous membrane amino groups was achieved by reaction with glutaraldehyde. Membranes were immersed in glutaraldehyde-water solution $(2.0 \%, \mathrm{v} / \mathrm{v}$, $100 \mathrm{~mL}$ ). The reaction was carried out at $30^{\circ} \mathrm{C}$ for $45 \mathrm{~min}$ with continuous stirring using an oscillator. Subsequently, activated membranes were removed and washed several times with deionized water before being dried in a vacuum oven for $6 \mathrm{~h}$ and stored at $4{ }^{\circ} \mathrm{C}$.

\subsubsection{Crystalline Transglutaminase Immobilization}

Immobilization of cross-linked crystalline transglutaminase onto modified poly(methyl methacrylate)grafted polypropylene microporous membrane $(3 \mathrm{~cm} \times 3 \mathrm{~cm}$ squares $)$ was performed by immersion in cross-linked crystalline transglutaminase solution $(15 \mathrm{mg} / \mathrm{mL}, 10 \mathrm{~mL})$ for $24 \mathrm{~h}$ at $4{ }^{\circ} \mathrm{C}$. Subsequently, membranes were washed with $0.03 \mathrm{M}$ sodium acetate buffer ( $\mathrm{pH}$ 6.0) to remove unbound cross-linked crystalline transglutaminase.

\subsubsection{Transglutaminase Activity Assay}

Transglutaminase activity was determined by hydroxamate formation from N-CBZ-Gln-Gly substrate, using the method described by Grossowicz et al. [42]. Substrate solution (1 mL), containing $0.2 \mathrm{M}$ Tris- $\mathrm{HCl}$ buffer $(\mathrm{pH} 6.0,0.4 \mathrm{~mL}), 0.1 \mathrm{M}$ hydroxylamine $(0.2 \mathrm{~mL}), 0.01 \mathrm{M}$ reduced glutathione $(0.2 \mathrm{~mL})$ and $0.15 \mathrm{M} \mathrm{N}$-CBZ-Gln-Gly $(0.2 \mathrm{~mL})$, was mixed with appropriately diluted enzyme solution 
$(0.4 \mathrm{~mL})$. The reaction mixture was incubated at $37{ }^{\circ} \mathrm{C}$ for $10 \mathrm{~min}$ and then stopped by adding ferric chloride trichloracetic acid reagent $(0.4 \mathrm{~mL}$, consisting of 1 volume $12 \% \mathrm{HCl}, 1$ volume $12 \%$ trichloracetic acid-TCA and 1 volume $5 \%$ ferric trichloride solution in $0.1 \mathrm{M} \mathrm{HCl}$ ). After $5 \mathrm{~min}$ centrifugation at $10,000 \mathrm{~g}$, the absorbance at $525 \mathrm{~nm}$ of the supernatant was measured. Enzyme activity was calibrated against a standard curve constructed using L-glutamic acid $\gamma$-monohydroxamate where one unit of transglutaminase was defined as the amount of enzyme which catalyzed the formation of $1.0 \mu \mathrm{mol} \mathrm{L}$-glutamic acid $\gamma$-monohydroxamate per minute at $37^{\circ} \mathrm{C}$.

\subsection{Optimal Temperature and pH Profile}

Temperature profiles of free, cross-linked and immobilized crystalline transglutaminase were measured by incubating the enzymes at $30,35,37,40,45,50,55$ and $60{ }^{\circ} \mathrm{C}$ for $10 \mathrm{~min}$. Transglutaminase activity was assayed as previously described. $\mathrm{pH}$ profiles of free, cross-linked and immobilized crystalline transglutaminase were measured by incubating the enzymes in buffer solutions over the $\mathrm{pH}$ range 2.0 to 10.0 for $10 \mathrm{~min}$ at the appropriate optimal temperature. Transglutaminase activity was assayed as previously described.

\subsection{Transglutaminase Stability}

The thermal stability of free, cross-linked and immobilized crystalline transglutaminase was measured in $0.2 \mathrm{M}$ Tris- $\mathrm{HCl}$ buffer solutions adjusted to the appropriate optimum $\mathrm{pH}$. Thermal stability was analyzed at 30, 40, 50, 60 and $70{ }^{\circ} \mathrm{C}$ for $120 \mathrm{~min}$. After cooling, the samples were allowed to equilibrate to room temperature for estimation of residual enzyme activity at $37{ }^{\circ} \mathrm{C}$ as previously described.

The $\mathrm{pH}$ stability of free, cross-linked and immobilized crystalline transglutaminase was measured in $0.2 \mathrm{M}$ Tris-HCl buffer solutions at the determined optimum temperature of the enzyme. $\mathrm{pH}$ stability was analyzed over the $\mathrm{pH}$ range 4.0 to 8.0 for $120 \mathrm{~min}$ at $40^{\circ} \mathrm{C}$. The $\mathrm{pH}$ of samples was then adjusted to approximately 5.5 and incubated at $37{ }^{\circ} \mathrm{C}$ for estimation of residual enzyme activity as previously described. Assay of untreated transglutaminase activity served as a control. Results are presented as the mean \pm standard deviation $(\mathrm{SD})$ of replicate measurements $(\mathrm{n}=3)$.

\subsection{Scanning Electron Microscopy}

Scanning electron microscopy (SEM) was used to study the cross-sectional morphology of free, cross-linked and immobilized crystalline transglutaminase. Furthermore, the surface characteristics of free and cross-linked crystalline transglutaminase were compared to those of immobilized cross-linked crystalline transglutaminase and native polypropylene microporous membrane. SEM analysis was performed using a SEMS-3400 (SEMS-3400, Hitachi Instrument Ltd., Japan) operated at a $20 \mathrm{kV}$ accelerating voltage.

\section{Conclusions}

Transglutaminase has become the focus of intense interest over recent years due to the potential industrial applications of the characteristic catalytic activity of this enzyme. In this study, the optimum 
conditions of temperature and $\mathrm{pH}$ for enzyme activity of free, cross-linked and immobilized transglutaminase were determined and compared. The optimum temperature for free transglutaminase activity was determined to be approximately $40{ }^{\circ} \mathrm{C}$, while increased values of approximately $45{ }^{\circ} \mathrm{C}$ and $50{ }^{\circ} \mathrm{C}$ were determined for cross-linked and immobilized transglutaminase, respectively. However, the optimal $\mathrm{pH}$ of 6.0 was not altered by cross-linking treatment or immobilization. After $120 \mathrm{~min}$ of incubation at $80{ }^{\circ} \mathrm{C}$, the residual activity of free transglutaminase was reduced to $23.2 \pm 1.05 \%$, while that of cross-linked and immobilized transglutaminase retained $72.6 \pm 1.86 \%$ and $74.8 \pm 2.06 \%$ residual activity, respectively. Free transglutaminase retained $24 \pm 1.88 \%$ residual activity at pH 9.0, whereas cross-linked and immobilized transglutaminase retained $60.1 \pm 1.05 \%$ and $62.5 \pm 1.62 \%$ residual activity, respectively. The broad range of $\mathrm{pH}$ and temperatures over which transglutaminase is active following immobilization on polypropylene microporous membrane suggests the potential application of this approach in the food industry.

\section{Acknowledgements}

This research was supported by grants from the National High Technology Research and Development Program of China (863 Project No. 2008AA10Z303) and the Program for Innovative Research Team in University of Heilongjiang Province (No. 2010td04).

\section{References and Notes}

1. Ikura, K.; Sasaki, R.; Motoki, M. Use of Transglutaminase in quality improvement and processing of food proteins. Comment. Agric. Food Chem. 1992, 2, 389-407.

2. Nielsen, P.M. Reactions and potential industrial applications of transglutaminase. Food Biotechnol. 1995, 9, 119-156.

3. Motoki, M.; Seguro, K. Transglutaminase and its use for food processing. Trends Food Sci. Technol. 1998, 9, 204-210.

4. Ohtsuka, T.; Sawa, A.; Kawabata, R.; Nio, N.; Motoki, M. Substrate specificities of microbial transglutaminase for primary amines. J. Agric. Food Chem. 2000, 48, 6230-6233.

5. Folk, J.E. Transglutaminase. Annu. Rev. Biochem. 1980, 49, 517-531.

6. Aeschlimann, D.; Paulsson, M. Transglutaminase: Protein cross-linking enzymes in tissues and body fluids. Thromb. Haemost. 1994, 71, 402-415.

7. Robert, E.F.; Whitaker, J.R. Food Proteins-Improvement Through Chemical and Enzymatic Modification: Symposium; American Chemical Society: Washington, DC, USA, 1977; p. 95.

8. Nio, N.; Motoki, M.; Takinami, K. Gelation of casein and soybean globulins by transglutaminase. Agric. Biol. Chem. 1986, 49, 2283-2286.

9. Nio, N.; Motoki, M.; Takinami, K. Gelation of protein emulsion by transglutaminase. Agric. Biol. Chem. 1986, 50, 1409-1412.

10. Eissa, A.S.; Khan, S.A. Acid-gelation of enzymatically modified, preheated whey proteins. J. Agric. Food Chem. 2005, 53, 5010-5017.

11. Gauche, C.; Tomazi, T.; Barreto, P.L.M.; Bordignon-Luiz, M.T. Physical properties of yoghurt manufactured with milk whey and transglutaminase. LWT-Food Sci. Technol. 2009, 42, 239-243. 
12. Truong, V.D.; Clare, D.A.; Catignani, G.L.; Swaisgood, H.E. Cross-linking and rheological changes of whey proteins treated with microbial transglutaminase. J. Agric. Food Chem. 2004, 52, 1170-1176.

13. Motoki, M.; Nio, N. Cross-linking between different food proteins by transglutaminase. J. Food Sci. 1983, 48, 561-566.

14. Ikura, K.; Kometani, T.; Sasaki, R.; Chiba, H. Cross-linking of soya bean 7S and 11S proteins by transglutaminase. Agric. Biol. Chem. 1980, 44, 2979-2984.

15. Ikura, K.; Kometani, T.; Yoshikawa, M.; Sasaki, R.; Chiba, H. Cross-linking of casein components by transglutaminase. Agric. Biol. Chem. 1980, 44, 1567-1573.

16. Kurth, L.; Rogers, P.J. Transglutaminase catalyzed cross-linking of myosin to soya protein, casein and gluten. J. Food Sci. 1984, 49, 573-576.

17. Tanimoto, S.Y.; Kinsella, J.E. Enzymatic modification of proteins: Effects of transglutaminase cross-linking on some physical properties of $\beta$-lactogloublin. J. Agric. Food Chem. 1988, 36, 281-285.

18. Aboumahmoud, R.; Savello, P. Cross-linking of whey protein by transglutaminase. J. Dairy Sci. 1990, 73, 256-263.

19. Ikura, K.; Okumura, K.; Yoshikawa, M.; Sasaki, R.; Chiba, H. Incorporation of lysyldipeptides into food protein by transglutaminase. Agric. Biol. Chem. 1985, 49, 1877-1878.

20. Yan, S.B.; Wold, F. Neoglycoproteins: In vitro introduction of glycosyl units at glutamines in $\beta$-casein using transglutaminase. Biochemistry 1984, 23, 3759-3765.

21. Yokoyama, K.; Nio, N.; Kikuchi, Y. Properties and applications of microbial transglutaminase. Appl. Microbiol. Biotechnol. 2004, 64, 447-454.

22. Colmenero, F.J.; Ayo, M.J.; Carballo, J. Physicochemical properties of low sodium frankfurter with added walnut: Effect of transglutaminase combined with caseinate, $\mathrm{KCl}$ and dietary fibre as salt replacers. Meat Sci. 2005, 69, 781-788.

23. Kuraishi, C.; Sakamoto, J.; Soeda, T. The usefulness of Transglutaminase for food processing in biotechnology for improved foods and flavors (ACS Symposium Series 637). In Biotechnology for Improved Foods and Flavors; Takeoka, G.R., Teranishi, R., Williams, P.J., Kobayashi, A., Eds.; American Chemical Society: Washington, DC, USA, 1996; pp. 29-38.

24. Seki, N.; Uno, H.; Lee, N.H.; Kimura, I.; Toyoda, K.; Fujita, T.; Arai, K. Transglutaminase activity in Alaska Pollack Muscle and Surimi, and its Reaction with Myosin B. Bull. Jpn. Soc. Sci. Fish. 1990, 56, 125-132.

25. Moore, M.M.; Heinbockel, M.; Dockery, P.; Ulmer, H.M.; Arendt, E.K. Network formation in gluten-free bread with application of transglutaminase. Cereal Chem. 2006, 83, 28-36.

26. Kumazawa, Y.; Nakanishi, K.; Yasueda, H.; Motoki, M. Purification and Characterization of Transglutaminase from Walleye Pollack Liver. Fish. Sci. 1996, 62, 959-964.

27. Trespalacios, P.; Pla, R. Simultaneous application of transglutaminase and high pressure to improve functional properties of chicken meat gels. Food Chem. 2007, 100, 264-272.

28. Herrero, A.M.; Cambero, M.I.; Ordóñez, J.A.; de la Hoz, L.; Carmona, P. Raman spectroscopy study of the structural effect of microbial transglutaminase on meat systems and its relationship with textural characteristics. Food Chem. 2008, 109, 25-32. 
29. Basaran, P.; Basaran-Akgul, N.; Rasco, B.A. Dielectric properties of chicken and fish muscle treated with microbial transglutaminase. Food Chem. 2010, 120, 361-370.

30. Gauche, C.; Barreto, P.L.M.; Bordignon-Luiz, M.T. Effect of thermal treatment on whey protein polymerization by transglutaminase: Implications for functionality in processed dairy foods. LWT-Food Sci. Technol. 2010, 43, 214-219.

31. O'Sullivan, M.M.; Kelly, A.L.; Fox, P.F. Effect of Transglutaminase on the Heat Stability of Milk: A Possible Mechanism. J. Dairy Sci. 2002, 85, 1-7.

32. Agyare, K.K.; Xiong, Y.L.; Addo, K. Influence of salt and $\mathrm{pH}$ on the solubility and structural characteristics of transglutaminase-treated wheat gluten hydrolysate. Food Chem. 2008, 107, 1131-1137.

33. Yasir, S.; Sutton, K.H.; Newberry, M.P.; Andrews, N.R.; Gerrard, J.A. The impact of transglutaminase on soy proteins and tofu texture. Food Chem. 2007, 104, 1491-1501.

34. Volken de Souza, C.F.; Venzke, J.G.; Flôres, S.H.; Ayub, M.A.Z. Enzymatic properties of transglutaminase produced by a new strain of Bacillus circulans BL32 and its action over food proteins. LWT-Food Sci. Technol. 2011, 44, 443-450.

35. Fagain, C.O. Enzyme stabilization-Recent experimental progress. Enzyme Microb. Technol. 2003, 33, 137-149.

36. Woodward, J. Immobilized Cells and Enzymes: A Practical Approach; IRL Press Ltd.: Oxford, UK, 1984.

37. Margolin, A.L. Novel crystalline catalysts. Trends Biotechnol. 1996, 14, 223-230.

38. Roy, J.J.; Abraham, T.E. Strategies in Making Cross-Linked Enzyme Crystals. Chem. Rev. 2004, 104, 3705-3722.

39. Sangha, O.H.; George, L.; Catignani; Swaisgood, H.E. Characteristics of an Immobilized Form of Transglutaminase: A Possible Increase in Substrate Specificity by Selective Interaction with a Protein Spacer. J. Agric. Food Chem. 1993, 41, 1337-1342.

40. Grim, M.D.; Kirst, H.A.; Yeh, W.K.; Zmijewski, M.J. Enzyme Technologies for Pharmaceutical and Biotechnological Applications; Marcel Dekker Inc.: New York, NY, USA, 2001; pp. 209-226.

41. Marcela, A.; Eduardo, H.; Michael, A.P.; Rafael, V. Cross-linked crystals of chloroperoxidase. Biochem. Biophys. Res. Commun. 2002, 295, 828-831.

42. Sanjay, G.; Sugunan, S. Enhanced $\mathrm{pH}$ and thermal stabilities of invertase immobilized on montmorillonite K-10. Food Chem. 2006, 94, 573-579.

43. Santos, A.M.P.; Oliveira, M.G.; Maugeri, F. Modelling thermal stability and activity of free and immobilized enzymes as a novel tool for enzyme reactor design. Bioresour. Technol. 2007, 98, 3142-3148.

44. Grossowicz, N.; Wainfan, E.; Borek, E. The enzymatic formation of hydroxamic acids from glutamine and asparagines. J. Biol. Chem. 1950, 187, 111-125.

Sample Availability: Contact the authors.

(C) 2011 by the authors; licensee MDPI, Basel, Switzerland. This article is an open access article distributed under the terms and conditions of the Creative Commons Attribution license (http://creativecommons.org/licenses/by/3.0/). 